\section{A platform for RNA}

\section{By Amy Donner, Senior Editor}

An information explosion on the number of functional RNA molecules expressed in cells and the mechanisms by which they control gene expression ${ }^{1,2}$ is driving the formation and funding of biotechs developing oligonucleotide-based therapeutics. Pharmas and big biotechs are carving up the space via partnerships that add multiple nucleic acid-based mechanisms and technologies to their drug discovery toolboxes.

The newest additions to the nucleic acid platform include noncoding RNA targets such as microRNAs and long noncoding RNAs (lncRNAs). Both types of molecule create the opportunity to selectively turn on expression of a given gene, potentially achieving biological and therapeutic outcomes that no other drug platform can.

Small molecules that interfere with the activity of chromatinmodifying enzymes can lead to the activation of many genes, but no small molecule or biologic has been shown to recapitulate the singlegene specificity achievable via the complementary base pairing of oligonucleotide-based modalities.

Although miRNAs and lncRNAs offer new targets and mechanisms, the modalities that target these molecules share one important feature with prior oligonucleotide-based therapeutics - the reliance on interactions between complementary nucleotides. Thus, therapeutics aimed at these new molecules share many of the challenges encountered with other nucleic acid-based agents.

These include delivering the drug to many tissue types, achieving levels of target engagement necessary for therapeutic effects and selecting and validating targets best suited to the modality.

\section{In the beginning}

Attempts to use antisense technology as a therapeutic began in the late 1980s. The rationale was clear-find a gene that is causing problems, synthesize a strand of nucleic acid that will bind to the mRNA and use that molecule to shut down the gene. However, a host of practical issues got in the way.

Oligonucleotide-based molecules are not drug like; thus, they require chemical modifications that improve their pharmacokinetics (see Figure 1, "Drug-like chemical modifications to nucleic acids"). In addition, there are multiple delivery challenges. For example, cells need to be coaxed into taking up oligonucleotide-based therapeutics and releasing enough of them from intracellular vesicles to elicit a therapeutic effect without activating an immune response.

Finally, the mechanism of action of some of these oligonucleotide molecules involves enzymatic degradation of the oligonucleotide-target complex. For example, antisense molecules elicit RNase $\mathrm{H}$-mediated degradation of their targets. ${ }^{3}$ Such mechanisms limit the range of pharmacological improvements that can be made to the molecules before they become unrecognizable to the relevant enzymes.

Two companies, Isis Pharmaceuticals Inc. and Santaris Pharma $\mathbf{A} / \mathbf{S}$, have taken the lead in addressing these issues and advancing the technology.

"Isis invented the antisense platform as a viable drug discovery and development approach," said Brett Monia, the company's SVP of antisense drug discovery.

"In the early years, we needed to partner early so that we could build a new technology. However, having a partner develop your drugs, especially something as different as antisense, is much less efficient and less profitable. Today, we hold on to our drugs much longer. The flexibility to partner a program at the optimal time is a huge advantage," Monia added.

Isis now has a pipeline of 19 antisense molecules in the clinic and 1 -mipomersen-on the market.

This year, the FDA approved mipomersen, which targets apolipoprotein $B-100(A P O B-100) \mathrm{mRNA}$, as an adjunct to lipid-lowering medications and diet to treat patients with homozygous familial hypercholesterolemia.

"The approval of mipomersen was a great moment for the advancement of oligonucleotide therapeutics," said John Maraganore, CEO of Alnylam Pharmaceuticals Inc.

Isis continues to be a prolific deal maker. Ten of its molecules in clinical testing are partnered, and the biotech recently announced a blockbuster neurology alliance with Biogen Idec Inc.

In addition to Isis, there are a handful of other companies with antisense therapeutics in the clinic, including Santaris (see Table 1, "Oligonucleotide therapeutic companies").

Santaris' locked nucleic acid (LNA) technology was one of the first and remains one of the best ways to improve the drug-like properties of oligonucleotides. LNAs increase an oligonucleotide's thermal stability, selectivity for the complementary target sequence and resistance to digestion by nucleases.

At least seven companies developing oligonucleotide-based drugs have licensed the technology from or partnered with Santaris, which has an internal pipeline of six antisense molecules in the clinic.

Rather than knocking down gene expression, at least two companies are taking a distinct approach - using antisense oligonucleotides to induce
"Many orphan diseases are caused by mutations in genes that cannot be targeted by other therapeutic modalities such as small molecules and monoclonal antibodies."

- John Maraganore, Alnylam Pharmaceuticals Inc. exon skipping. In this approach, an antisense oligonucleotide blocks access of the splicing machinery to the target, which is unspliced pre-mRNA, resulting in the adjacent exon being skipped or omitted from the mature mRNA.

Omission of an exon that does not disrupt the translational reading frame results in the production of a smaller but at least partially functional protein. 
Figure 1. Drug-like chemical modifications to nucleic acids. Nucleic acids are not drug-like molecules, and chemical modifications are required to improve their pharmacokinetic and other properties before they can be used as therapeutics. Several examples are illustrated. (I) Locked nucleic acids (LNAs) are modified nucleotides with an additional bond between the 2 '-oxygen and 4'-carbon of the ribose sugar. Santaris Pharma A/S owns the rights to the therapeutic application of these molecules. (II) Modifications to the phosphodiester backbone include phosphorothioate (PS) or phosphorodiamidate linkages. PS linkages are part of Isis Pharmaceutical Inc.'s first-generation chemistry, and phosphorodiamidate morpholino oligonucleotides (PMOs) were developed by Sarepta Therapeutics Inc. (III) 2'-O-methoxyethyl, Isis' secondgeneration chemistry, or 2'-O-Me, in Silence Therapeutics plc's AtuRNAis, are also modifications to the ribose sugar.

For example, in most cases of Duchenne muscular dystrophy (DMD), a deletion in the dystrophin gene disrupts the translational reading frame, thus inhibiting expression of the protein. Antisense oligonucleotides that induce skipping of exon 51 partially rescue dystrophin function. However, it is not yet clear if this approach is working in DMD.

In September, GlaxoSmithKline plc and Prosensa Holding N.V. announced that the biotech's drisapersen, an RNA-based antisense drug that induces exon 51 skipping in the dystrophin gene, failed in a Phase III study.

Sarepta Therapeutics Inc.'s eteplirsen, a phosphorodiamidate morpholino oligomer (PMO)-based antisense molecule that also induces skipping of exon 51 of the dystrophin gene, has completed Phase IIb testing.

The 24-week Phase IIb trial enrolled 12 patients, 2 of whom dropped out at week 24 because of rapidly progressing disease, leaving 10 patients in the modified intent-to-treat (mITT) arm who entered a 72-week open-label extension.

The Phase IIb trial met its primary endpoint of increased dystrophinpositive muscle fibers versus placebo at week 24 , although neither eteplirsen dose significantly improved placebo-adjusted 6-minute walk distance (6MWD), the standard clinical endpoint for DMD trials. Subsequent data points from the extension at 36, 48, 62 and 74 weeks showed that eteplirsen significantly improved 6MWD versus placebo.

Sarepta plans to submit an NDA to the FDA in early 2014.

Moderna Therapeutics Inc., founded in 2010 by Flagship Ventures, is developing oligonucleotide-based therapeutics that directly encode the expression of human proteins in vivo. The biotech is not using or targeting noncoding RNAs and instead has developed a chemically unique RNA-based platform.

In 3 years, Moderna has filed 144 patent applications covering 6,910 claims, including new chemical modifications, RNA engineering, formulation, composition of matter, route of administration and dosing paradigms.

\section{Running interference}

In 2001, small interfering RNAs, which feed into the RNAi pathway (see Figure 2, "The RNAi pathway"), were shown to lead to mRNA degradation in cultured human cells. ${ }^{4}$ In contrast with their

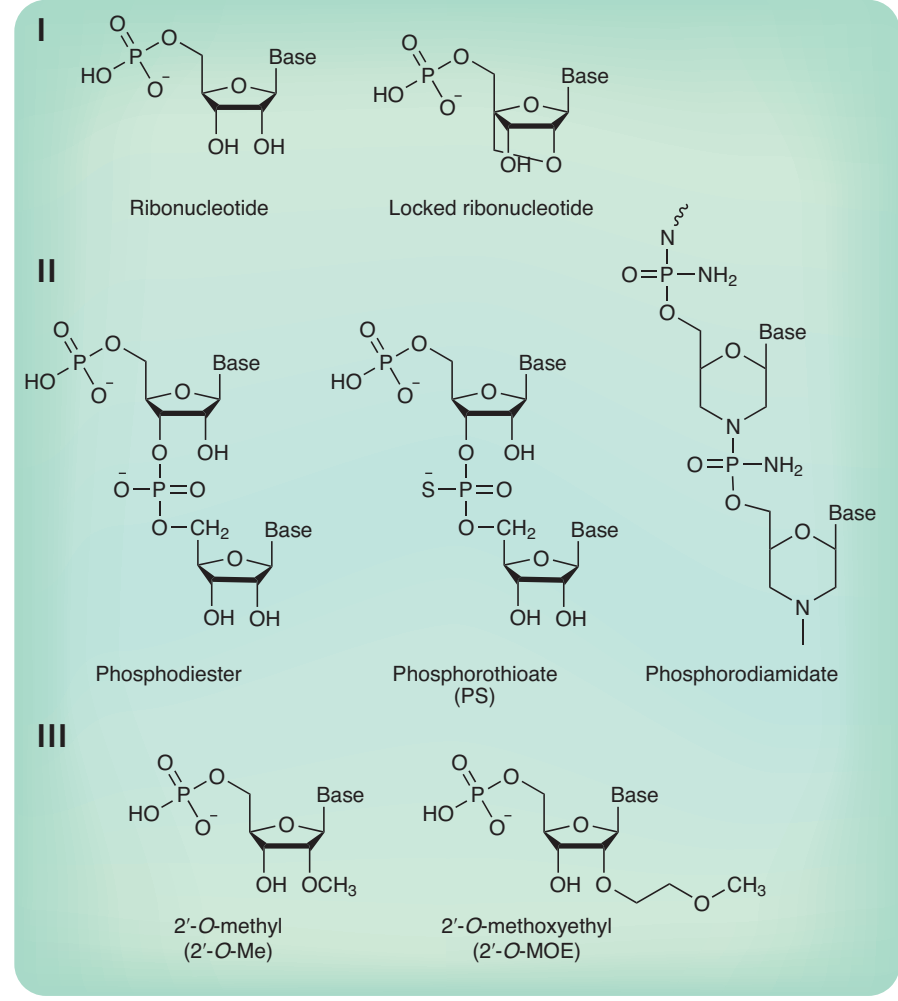

single-stranded antisense counterparts, siRNA therapeutics are double stranded.

Companies developing siRNA-based therapeutics have been particularly challenged by delivery, as double-stranded oligonucleotides are notably worse than their single-stranded counterparts at accessing the intracellular space in which most RNA targets are found. Indeed single-stranded antisense modalities can often be delivered in saline, whereas double-stranded molecules require a vehicle to get them across the plasma membrane.

Alnylam has pioneered the development of siRNA therapeutics, with a focus on orphan indications in which drugs need to be targeted to the liver, which is where lipid nanoparticles carrying siRNA can accumulate. $^{5}$

According to Maraganore, "Many orphan diseases are caused by mutations in genes that cannot be targeted by other therapeutic modalities such as small molecules and monoclonal antibodies."

Alnylam's $N$-acetylgalactosamine (GalNAc)-siRNA conjugates consist of siRNAs linked to three GalNAc residues to achieve efficient hepatocyte-specific delivery. GalNAcs are recognized by asialoglycoprotein receptor 1 (ASGR1; CLEC4H1), which is abundantly expressed on hepatocytes.

In March, Alnylam started Phase I testing of ALN-TTRsc, an siRNA that targets transthyretin (TTR) mRNA to treat TTR-mediated amyloidosis (ATTR).

"We've shown that we can knock down TTR by up to $94 \%$ in human studies. The drug was found to have a very encouraging safety profile. In short, GalNAc-siRNA opens up the door for RNAi therapeutics in a much broader range of clinical indications," said Maraganore.

Another company that has tackled the siRNA delivery issue is Tekmira Pharmaceuticals Corp., which uses stable nucleic acid-lipid 
Figure 2. The RNAi pathway. MicroRNAs are transcribed in the nucleus as precursor pri-miRNAs, which form hairpins that are processed to mature miRNAs by two RNase III enzymes, drosha and dicer. [a(1)] The premiRNA product produced by drosha cleavage is exported to the cytoplasm, where dicer processes it to a duplex of 20-25 nucleotides. [b] One strand of the duplex is incorporated into the RNA-induced silencing complex (RISC). The miRNA recognizes target mRNAs by the complementary base pairing. [c] Perfect complementarity leads to cleavage of the target mRNA. [a(2)] Small interfering RNAs enter the pathway in the cytoplasm, just upstream of the RNA loading into RISC. siRNA and miRNA companies have adopted different strategies to use this same pathway to achieve therapeutic outcomes. The major mechanism or step at which companies intervene in the RNAi pathway is indicated.

particles (SNALPs). The company gained the technology via its 2008 purchase of Protiva Biotherapeutics Inc.

Alnylam's lead compound, ALN-TTR02, uses SNALP technology from Tekmira for delivery. This year, Alnylam reported positive results from its Phase II trial of ALN-TTR02 to treat ATTR.

Tekmira's lead program, TKM-PLK, uses SNALP to deliver an siRNA targeting polo-like kinase 1 (PLK1; STPK13) mRNA. The molecule is in Phase I/II testing to treat neuroendocrine tumors and adrenocortical carcinoma. Results are expected in mid-2014.

There are at least 13 companies focused on siRNA therapeutics.

\section{Micro economics}

The space that has seen the most new company formation in recent years is miRNAs, which are naturally occurring noncoding RNAs that function like siRNAs in the RNAi pathway. They are about 22 nucleotides in length and regulate the expression of gene networks by interacting with the $3^{\prime}$ untranslated region of mRNAs and blocking translation or regulating degradation of their targets. Dysregulation of miRNAs was first linked to human disease in $2002 .^{6}$

Anti-miRNAs are synthetic antisense oligonucleotides that target miRNAs and thereby inhibit their function, usually resulting in the upregulation of gene expression. Similar to antisense molecules targeting mRNAs, anti-miRNAs are often single stranded and with the right nucleic acid chemistry can be delivered in saline.

miRNA mimics are synthetic, double-stranded oligonucleotides designed to replace miRNA function. Similar to siRNAs, these molecules inhibit gene expression. Because they are double stranded, delivery vehicles are generally necessary for these molecules to reach intracellular targets.
In 2007, Isis and Alnylam combined their miRNA-directed programs and formed Regulus Therapeutics Inc., the first purely miRNA-based therapeutics company. ${ }^{7}$ Regulus received exclusive rights to both Isis' and Alnylam's technologies covering the therapeutic application of antimiRNAs.

Last year, Regulus raised \$50.9 million in an IPO, \$25 million from the concurrent sale of stock to AstraZeneca plc and Isis and \$5 million from the sale of a convertible note to Biogen.

In 2014, Regulus expects to submit an IND for lead compound RG-101, a GalNAc-conjugated anti-miRNA targeting hepatocyte miR122 , to treat HCV.

Regulus was not alone in the miRNA space for very long. Mirna Therapeutics Inc. and miRagen Therapeutics Inc. also were founded in 2007.

Mirna is focused on miRNA replacement therapies for cancer. The company's lead candidate is MRX34, a liposomally formulated miR-34 mimic that is in Phase I testing to treat liver cancer.

miRagen is using Santaris' LNA technology to develop miRNAtargeted therapies. miRagen has a deal with Servier in cardiovascular disease, and its programs are in preclinical development.

MiReven Pty. Ltd. is a newer entrant in the miRNA space. The company was formed in 2010 and has miR-7 mimics in preclinical development to treat cancer. It partnered with Silence Therapeutics plc last year for the latter's lipid-based delivery technology. 
Table 1. Oligonucleotide therapeutic companies. Source: BCIQ: BioCentury Online Intelligence; company press releases and websites

\begin{tabular}{|c|c|c|}
\hline Company & Modality & $\begin{array}{l}\text { Stage of lead } \\
\text { compound }\end{array}$ \\
\hline Antisense Therapeutics Ltd. (ASX:ANP) & Antisense & $\begin{array}{l}\text { Phase IIa } \\
\text { complete }\end{array}$ \\
\hline iCo Therapeutics Inc. (TSX-V:ICO) & Antisense & Phase II \\
\hline Isarna Therapeutics GmbH & Antisense & Phase II \\
\hline Isis Pharmaceuticals Inc. (NASDAQ:ISIS) & Antisense & Marketed \\
\hline $\begin{array}{l}\text { OncoGenex Pharmaceuticals Inc. } \\
\text { (NASDAQ:OGXI) }\end{array}$ & Antisense & Phase III \\
\hline Prosensa Holding N.V. (NASDAQ:RNA) & Antisense & Phase III \\
\hline Santaris Pharma A/S & Antisense & Phase $\mathrm{I}^{\mathrm{A}}$ \\
\hline Sarepta Therapeutics Inc. (NASDAQ:SRPT) & Antisense & Phase II \\
\hline Xenon Pharmaceuticals Inc. & Antisense & Preclinical \\
\hline $\begin{array}{l}\text { Alnylam Pharmaceuticals Inc. } \\
\text { (NASDAQ:ALNY) }\end{array}$ & $\begin{array}{l}\text { Small } \\
\text { interfering } \\
\text { RNA }\end{array}$ & Phase II \\
\hline $\begin{array}{l}\text { Arrowhead Research Corp. } \\
\text { (NASDAQ:ARWR) }\end{array}$ & siRNA & Phase I \\
\hline Benitec Biopharma Ltd. (ASX:BLT) & siRNA & Preclinical \\
\hline Dicerna Pharmaceuticals Inc. & siRNA & Preclinical \\
\hline Marina Biotech Inc. (OTCQX:MRNA) & siRNA & Phase I \\
\hline ProNAi Therapeutics Inc. & siRNA & Phase II \\
\hline RXi Pharmaceuticals Corp. (OTCQX:RXII) & siRNA & Phase I \\
\hline SBI Biotech Co. Ltd. & siRNA & Phase II \\
\hline Silence Therapeutics plc (LSE:SLN) & siRNA & Phase II \\
\hline Sylentis S.A. & siRNA & Phase I \\
\hline $\begin{array}{l}\text { Tekmira Pharmaceuticals Corp. } \\
\text { (TSX:TKM; NASDAQ:TKMR) }\end{array}$ & siRNA & Phase I \\
\hline TransDerm Inc. & siRNA & Phase I \\
\hline InteRNA Technologies B.V. & MicroRNA & Preclinical \\
\hline miRagen Therapeutics Inc. & miRNA & Preclinical \\
\hline Mirna Therapeutics Inc. & miRNA & Phase I \\
\hline MiReven Pty Ltd. & miRNA & Preclinical \\
\hline $\begin{array}{l}\text { Regulus Therapeutics Inc. } \\
\text { (NASDAQ:RGLS) }\end{array}$ & anti-miRNA & Preclinical \\
\hline RXi Pharmaceuticals & $\begin{array}{l}\text { Long } \\
\text { noncoding } \\
\text { RNA }\end{array}$ & Undisclosed \\
\hline RaNA Therapeutics Inc. & $\operatorname{lncRNA}$ & Undisclosed \\
\hline
\end{tabular}

ASantaris' lead program is an anti-miRNA in Phase II.

InteRNA Technologies B.V. also has miRNA-based therapeutics for cancer in preclinical development.

Santaris was the first company to bring a miRNA-targeting molecule into the clinic. The company's miravirsen, an LNA-modified antimiRNA that targets hepatocyte miR-122, is in Phase II testing to treat HCV. In 2013, Santaris published Phase IIa data showing that miravirsen resulted in a dose-dependent reduction in HCV RNA levels. ${ }^{8}$

Santaris also has anti-miRNAs in preclinical development.

\section{The long noncoding road}

Even newer than miRNAs are lncRNAs, which are noncoding RNA targets that can positively and negatively regulate gene expression. ${ }^{9}$

Studies of newly discovered lncRNAs are revealing previously unknown regulatory mechanisms that control gene expression, although strategies for targeting or mimicking these molecules share many of the chemical, biological and logistical traits of siRNA and antisense therapeutics.

Two studies formed the foundation for the first companies focused on therapeutics targeting lncRNAs.

In 2010, scientists in the laboratory of Jeannie Lee showed that a histone methyltransferase called polycomb repressive complex 2 (PRC2) interacted with more than 9,000 RNAs, many of which had not previously been annotated. ${ }^{10}$ Based on the findings, the group proposed that lncRNAs can drive target-specific interactions between chromatinmodifying complexes and genomic DNA.

Lee is a professor of genetics and pathology at Harvard Medical School and Massachusetts General Hospital and Howard Hughes Medical Institute investigator.

In 2011, Lee cofounded RaNA Therapeutics Inc., which received seed funding from Atlas Venture. The biotech is developing oligonucleotidebased therapeutics to disrupt lncRNAs that recruit PRC2 to promoters. The compounds control the expression of therapeutically relevant proteins by specifically upregulating their expression.

"Our focus is on the selective upregulation of a therapeutic protein that has already been validated as important in disease," said Art Krieg, president, CEO and cofounder of RaNA.

RaNA has in vitro proof of concept that an oligonucleotide-based agent can specifically alter expression of a target gene by disrupting interactions between lncRNA and PRC2.

The company has programs in spinal muscular atrophy and Friedreich's ataxia and hopes to advance a molecule into the clinic in 2015, said Krieg.

In January 2012, RaNA raised \$20.7 million in a series A round led by Atlas, SR One and Monsanto Co. RaNA has a proprietary database of more than 50,000 PRC2-associated lncRNAs and owns 28 patent applications.

The second seminal study in the lncRNA field was published in 2012 by a group led by Claes Wahlestedt. The team showed that antagonizing lncRNAs that function as natural antisense transcripts (NATs) de-repressed and thus activated the expression of a specific gene. ${ }^{11}$ The work also showed that a nucleic acidbased modality called an antagoNAT could achieve interference with NATs in vivo.

Wahlestedt is associate dean for therapeutic innovation, director of the Center for Therapeutic Innovation and a professor of psychiatry and
"Pharma is becoming more modality agnostic instead of just summarily dismissing oligos as drugs. They are primarily now just looking at these agents as drugs."

-Art Krieg, RaNA Therapeutics Inc. behavioral sciences at the University of Miami Miller School of Medicine.

In 2008, Wahlestedt, then a professor of molecular therapeutics and adjunct professor of molecular and integrative neuroscience at Scripps Florida, cofounded Curna Inc. with a \$350,000 loan from the town of Jupiter, Fla., to commercialize the antagoNAT strategy for upregulating expression of therapeutically relevant proteins.

In February 2011, Opko Health Inc. acquired Curna for \$10 million. 
Table 2. Recent deals. Deals between Isis Pharmaceuticals Inc. and Biogen Idec Inc., and Moderna Therapeutics Inc. and AstraZeneca plc, highlight increasing investments in oligonucleotide-based therapeutics.

\begin{tabular}{ll}
\hline $\begin{array}{l}\text { Company } \\
\begin{array}{l}\text { Alnylam Pharmaceuticals } \\
\text { Inc. } \\
\text { (NASDAQ:ALNY) }\end{array}\end{array}$ & $\begin{array}{l}\text { Gartner } \\
\text { (LSE:GSK; NYSE:GSK) }\end{array}$ \\
\hline & Sylentis S.A. \\
\hline & $\begin{array}{l}\text { Arrowhead Research } \\
\text { Corp. } \\
\text { (NASDAQ:ARWR) }\end{array}$ \\
& $\begin{array}{l}\text { Ascletis Pharmaceuticals } \\
\text { Co. Ltd. }\end{array}$ \\
& $\begin{array}{l}\text { Monsanto Co. } \\
\text { (NYSE:MON) }\end{array}$ \\
& $\begin{array}{l}\text { Genzyme Corp. unit of } \\
\text { Sanofi (Euronext:SAN; } \\
\text { NYSE:SNY) }\end{array}$ \\
& $\begin{array}{l}\text { The Medicines Co. } \\
\text { (NASDAQ:MDCO) }\end{array}$ \\
\hline
\end{tabular}

\begin{tabular}{lll}
\hline Arrowhead Research & Axolabs GmbH & Strategic alliance \\
\hline $\begin{array}{l}\text { Benitec Biopharma Ltd. } \\
\text { (ASX:BLT) }\end{array}$ & Calimmune Inc. & $\begin{array}{l}\text { Nonexclusive worldwide license for the use of } \\
\text { DNA-directed RNAi (ddRNAi) platform for up to } \\
\text { three targets in HIV/AIDS }\end{array}$ \\
\hline & $\begin{array}{l}\text { Genable Technologies } \\
\text { Ltd. }\end{array}$ & $\begin{array}{l}\text { Worldwide license for use of ddRNAi platform for } \\
\text { retinitis pigmentosa }\end{array}$ \\
\hline
\end{tabular}

\section{Deal description}

VaxiRNA to speed vaccine production
Collaboration on RNAi technology called

\section{Financial terms \\ Undisclosed}

Date

Nonexclusive license for the discovery, development Undisclosed

and commercialization of small interfering RNA

therapeutic in glaucoma

License to discover, develop and commercialize an RNAi therapeutic targeting HBV. Alnylam

received rights to Arrowhead's Dynamic polyconjugate delivery technology

Exclusive rights to develop and commercialize ALN-VSP for liver cancer in China

Worldwide exclusive rights to Alnylam's platform technology and IP in agriculture

Licensed rights to transthyretin-mediated amyloidosis (ATTR) program in Asia

Exclusive global alliance for the development and commercialization of ALN-PCS for hypercholesterolemia

Undisclosed

Jan. 2012

Nov. 2011

(1)

July 2012

Undisclosed

$\$ 29.2$ million upfront

and milestones

\$22.5 million upfront

Aug. 2012

and milestones

\$25 million upfront

and up to $\$ 180$ million in milestones

Feb. 2013

Undisclosed

March 2012

Undisclosed

March 2012

Undisclosed

July 2012

More than 102 million new shares issued ( $\sim 1.5$ million) plus future royalties and licensing revenues

Tacere Therapeutics Inc. Acquisition Regen BioPharma Inc. subsidiary of Bio-Matrix Scientific Group Inc. (OTCBB:BMSN)

License agreement for use of ddRNAi platform to block immunosuppression in cancer

Undisclosed

Alliance to advance antisense therapeutics for neurological disease

\begin{tabular}{ll}
$\begin{array}{l}\text { Isis Pharmaceuticals } \\
\text { (NASDAQ:ISIS) }\end{array}$ & $\begin{array}{l}\text { Biogen Idec } \\
\text { (NASDAQ:BIIB) }\end{array}$ \\
\hline
\end{tabular}

AstraZeneca (LSE:AZN; NYSE:AZN)

Marina Biotech Inc. (OTCQX:MRNA)

Mirna Therapeutics Inc.

Alliance to discover and develop antisense therapeutics against five targets in cancer

License agreement for the development and commercialization of microRNA replacement therapy in cancer

Exclusive license for the development and ProNAi Therapeutics Inc. commercialization of DNAi-based therapeutics Exclusive license agreement for Marina's delivery technologies and chemistry

Nonexclusive license agreement for use of Marina's nucleic acid chemistry

Novartis AG (NYSE:NVS; SIX:NOVN)

Tekmira Pharmaceuticals

Corp.

(TSX:TKM;

NASDAQ:TKMR)

Worldwide, nonexclusive rights to Marina's nucleic acid chemistry for RNAi therapeutics

\section{Arcturus Therapeutics Assigned unlocked nucleic acid chemistry to}

Inc.

Arcturus

$\$ 100$ million upfront plus milestone payments up to $\$ 220$ million

\$31 million upfront,

near-term payments of another

$\$ 31$ million and milestones

Oct. 2012

Aug. 2013

Collaboration combining Silence's delivery platform with miRagen's drug candidates (LSE:SLN)

Commercialization rights outside of the US and Japan for three drugs in cardiovascular disease
Up to $\$ 63$ million upfront and

Dec. 2011

milestones

\$14 million upfront for each target March 2012 plus milestones

Undisclosed

May 2012

Aug. 2012

\$1 million

Nov. 2012
Undisclosed

Undisclosed

Aug. 2013

Jan. 2011

$\$ 45$ million upfront and up to

$\$ 352$ million in milestones
Oct. 2011
Servier

apan 


\begin{tabular}{|c|c|c|c|c|}
\hline $\begin{array}{l}\text { Moderna Therapeutics } \\
\text { Inc. }\end{array}$ & AstraZeneca & $\begin{array}{l}\text { Exclusive agreement to develop up to } 40 \text { mRNA } \\
\text { therapeutics to treat cardiometabolic disease and } \\
\text { cancer }\end{array}$ & $\begin{array}{l}\$ 240 \text { million upfront and up to } \\
\$ 180 \text { million in milestones }\end{array}$ & March 2013 \\
\hline Opko Health Inc. & $\begin{array}{l}\text { RXi Pharmaceuticals } \\
\text { Corp. } \\
\text { (NASDAQ:RXII) }\end{array}$ & Rxi acquires Opko's RNAi-related assets & $\begin{array}{l}\text { Rxi will issue Opko } 50 \text { million shares } \\
\text { and make milestone payments up to } \\
\$ 50 \text { million }\end{array}$ & March 2013 \\
\hline $\begin{array}{l}\text { Prosensa Holding B.V. } \\
\text { (NASDAQ:RNA) }\end{array}$ & GlaxoSmithKline & $\begin{array}{l}\text { Collaboration to advance three exon-skipping } \\
\text { therapeutics to treat Duchenne muscular dystrophy } \\
\text { (DMD) }\end{array}$ & Up to $\sim \$ 37$ million & Sept. 2013 \\
\hline $\begin{array}{l}\text { Regulus Therapeutics Inc. } \\
\text { (NASDAQ: RGLS) }\end{array}$ & AstraZeneca & $\begin{array}{l}\text { Alliance to discover, develop and commercialize } \\
\text { therapeutics targeting up to three miRNAs in } \\
\text { cardiovascular disease, metabolic disease and } \\
\text { oncology }\end{array}$ & $\$ 28$ million upfront and equity & Aug. 2012 \\
\hline $\begin{array}{l}\text { Roche } \\
\text { (SIX:ROG; } \\
\text { OTCQX:RHHBY) }\end{array}$ & Arrowhead & Acquisition of Roche's RNA therapeutic assets & $\begin{array}{l}\text { Roche obtained a minority stake in } \\
\text { Arrowhead and milestones }\end{array}$ & Oct. 2011 \\
\hline \multirow[t]{4}{*}{ Santaris Pharma A/S } & Pfizer Inc. (NYSE:PFE) & Expanded worldwide strategic alliance to 10 targets & $\begin{array}{l}\$ 14 \text { million upfront and up to } \\
\$ 600 \text { million in milestones }\end{array}$ & Jan. 2011 \\
\hline & Miragen & $\begin{array}{l}\text { Expanded worldwide strategic alliance by up to six } \\
\text { miRNA targets }\end{array}$ & Undisclosed & Jan. 2013 \\
\hline & $\begin{array}{l}\text { Bristol-Myers Squibb Co. } \\
\text { (NASDAQ:BMY) }\end{array}$ & $\begin{array}{l}\text { Worldwide strategic alliance to discover and } \\
\text { develop locked nucleic acid (LNA)-based } \\
\text { therapeutics targeting mRNA or miRNA }\end{array}$ & $\begin{array}{l}\$ 10 \text { million upfront and up to } \\
\$ 90 \text { million in milestones }\end{array}$ & April 2013 \\
\hline & RaNA & $\begin{array}{l}\text { License for LNA-based therapeutics on up to } 10 \\
\text { targets for selective activation of protein expression }\end{array}$ & Undisclosed & July 2013 \\
\hline \multirow[t]{2}{*}{$\begin{array}{l}\text { Silence Therapeutics plc } \\
\text { (LSE:SLN) }\end{array}$} & $\begin{array}{l}\text { InteRNA Technologies } \\
\text { B.V. }\end{array}$ & $\begin{array}{l}\text { Collaboration to develop miRNA therapeutics to } \\
\text { treat cancer }\end{array}$ & Undisclosed & Sept. 2011 \\
\hline & MiReven Pty. Ltd. & $\begin{array}{l}\text { Collaboration to combine Silence's delivery } \\
\text { technology with MiReven's therapeutics }\end{array}$ & Undisclosed & Aug. 2012 \\
\hline Tekmira & Alnylam & $\begin{array}{l}\text { Resolves litigation over stable nucleic acid-lipid } \\
\text { particle (SNALP) delivery technology and extends } \\
\text { licensing agreement }\end{array}$ & $\begin{array}{l}\$ 65 \text { million upfront and up to } \\
\$ 10 \text { million in milestones }\end{array}$ & Nov. 2012 \\
\hline
\end{tabular}

About 2 years later, RXi Pharmaceuticals Corp. acquired Opko Health's RNAi-related assets for about $\$ 7$ million in stock and up to $\$ 50$ million in development and commercialization milestones for each product. At the time it was acquired by Opko Health, Curna had filed for at least 90 patents.

\section{Big pharma's big place}

Over the now several decades-long history of nucleic acid therapeutics, big pharma has had an on-again, off-again relationship with the technology.

According to Maraganore, "In the 2005-2009 period, big pharma made big bets on RNAi technology platforms. Unfortunately, some of the big pharma technology efforts have not been so successful, at least as measured by IND filings, of which there are none."

In 2010, Roche abandoned its internal efforts to develop RNAi as a drug platform. In early 2011, Pfizer Inc. announced that it was cutting its RNAi drug discovery programs among others as part of a restructuring plan. Abbott Laboratories soon followed suit.

Also in 2011, Merck \& Co. Inc. shut down the San Francisco RNAi research site that had been Sirna Therapeutics Inc., which it had acquired for $\$ 1.1$ billion in 2006, but said it remained committed to RNAi technology. Merck and Novartis AG are the only big pharmas that have disclosed internal, RNA-directed therapeutics programs.

Table 3. Oligonucleotide toolkits. Through a host of partnerships, many pharmas now have the ability to target multiple types of RNAs using multiple modalities.

\begin{tabular}{lccc}
\hline Company & Antisense & $\begin{array}{c}\text { Small interfering } \\
\text { RNA }\end{array}$ & $\begin{array}{c}\text { MicroRNA (anti-miRNAs } \\
\text { and miRNA mimics) }\end{array}$ \\
\hline $\begin{array}{l}\text { AstraZeneca plc (LSEA:ZN; NYSE:AZN) } \\
\text { Oristol-Myers Squibb Co. }\end{array}$ & $\mathrm{X}$ & $\mathrm{X}$ \\
$\begin{array}{l}\text { (NYSE:BMY) } \\
\text { GlaxoSmithKline plc (LSE:GSK; NYSE:GSK) }\end{array}$ & $\mathrm{X}$ & $\mathrm{X}$ \\
\hline $\begin{array}{l}\text { Novartis AG (NYSE:NVS; SIX:NOVN) } \\
\text { Pfizer Inc. } \\
\text { (NYSE:PFE) }\end{array}$ & $\mathrm{X}$ & $\mathrm{X}$ & $\mathrm{X}$ \\
\hline $\begin{array}{l}\text { Sanofi } \\
\text { (Euronext:SAN; NYSE:SNY) }\end{array}$ & $\mathrm{X}$ & $\mathrm{X}$ & $\mathrm{X}$ \\
\hline AModerna Therapeutics Inc.'s messenger RNA therapeutics. & $\mathrm{X}$ & $\mathrm{X}$ & $\mathrm{X}$ \\
\hline
\end{tabular}




\section{ANALYSIS}

In October of this year, Merck said it was restructuring R\&D. The pharma did not say whether cuts will include its RNAi platform.

Instead of building their own nucleic acid-based platforms, most pharmas have chosen to partner with biotechs to develop nucleic acid therapeutics (see Table 2, "Recent deals" and Table 3, "Oligonucleotide toolkits").

According to Krieg, "Pharma is becoming more modality agnostic instead of just summarily dismissing oligos as drugs. They are primarily now just looking at these agents as drugs."

Maraganore agreed. "RNAi therapeutics partnerships will be focused on product alliances. Pharma has recently grown their interest in the RNA therapeutics space but with an interest in products, not technology," he said.

Donner, A. SciBX 6(41); doi:10.1038/scibx.2013.1151

Published online Oct. 24, 2013

\section{REFERENCES}

1. Djebali, S. et al. Nature 489, 101-108 (2012)

2. ENCODE Project Consortium. Nature 489, 57-74 (2012)

3. Kole, R. et al. Nat. Rev. Drug Discov. 11, 125-140 (2012)

4. Elbashir, S.M. et al. Nature 411, 494-498 (2001)

5. McCallister, E. BioCentury 21(15), A1-A6; April 15, 2013

6. Calin, G.A. et al. Proc. Natl. Acad. Sci. USA 99, 15524-15529 (2002)

7. Mujtaba, U. BioCentury 15(41), A9; Sept. 17, 2007

8. Janssen, H.L.A. et al. N. Engl. J. Med. 368, 1685-1694 (2013)

9. Wahlestedt, C. Nat. Rev. Drug Discov. 12, 433-446 (2013)

10. Zhao, J. et al. Mol. Cell 40, 939-953 (2010)

11. Modarresi, F. et al. Nat. Biotechnol. 30, 453-459 (2012)

COMPANIES AND INSTITUTIONS MENTIONED

Abbott Laboratories (NYSE:ABT), Abbott Park, III.
Alnylam Pharmaceuticals Inc. (NASDAQ:ALNY), Cambridge, Mass. AstraZeneca plc (LSE:AZN; NYSE:AZN), London, U.K. Atlas Venture, Cambridge, Mass.

Biogen Idec Inc. (NASDAQ:BIIB), Weston, Mass.

Flagship Ventures, Cambridge, Mass.

GlaxoSmithKline plc (LSE:GSK; NYSE:GSK), London, U.K. Harvard Medical School, Boston, Mass.

Howard Hughes Medical Institute, Chevy Chase, Md. InteRNA Technologies B.V., Nijmegen, the Netherlands Isis Pharmaceuticals Inc. (NASDAQ:ISIS), Carlsbad, Calif. Massachusetts General Hospital, Boston, Mass.

Merck \& Co. Inc. (NYSE:MRK), Whitehouse Station, N.J. miRagen Therapeutics Inc., Boulder, Colo.

MiReven Pty. Ltd., Perth, Western Australia, Australia

Mirna Therapeutics Inc., Austin, Texas

Moderna Therapeutics Inc., Cambridge, Mass.

Monsanto Co. (NYSE:MON), St. Louis, Mo.

Novartis AG (NYSE:NVS; SIX:NOVN), Basel, Switzerland

Opko Health Inc., Miami, Fla.

Pfizer Inc. (NYSE:PFE), New York, N.Y.

Prosensa Holding N.V. (NASDAQ:RNA), Leiden, the Netherlands RaNA Therapeutics Inc., Cambridge, Mass.

Regulus Therapeutics Inc. (NASDAQ:RGLS), Carlsbad, Calif.

Roche (SIX:ROG; OTCQX:RHHBY), Basel, Switzerland

RXi Pharmaceuticals Corp. (NASDAQ:RXII), London, U.K.

Santaris Pharma A/S, Horsholm, Denmark

Sarepta Therapeutics Inc. (NASDAQ:SRPT), Cambridge, Mass. Scripps Florida, Jupiter, Fla.

Servier, Neuilly-sur-Seine, France

Silence Therapeutics plc (LSE:SLN), London, U.K.

SR One, Cambridge, Mass.

Tekmira Pharmaceuticals Corp. (TSX:TKM; NASDAQ:TKMR), Burnaby, British Columbia, Canada

University of Miami Miller School of Medicine, Miami, Fla. 